\title{
Global growth trend in fisheries and current situation in Turkey
}

\section{Dünya su ürünleri geliş̧im trendi ve Türkiye’nin durumu}

\author{
Hasan Arısoy1 • Zeki Bayramoğlu2 • Kemalettin Ağızan ${ }^{3 *}$ • Süheyla Ağızan ${ }^{4}$ \\ ${ }^{1}$ Selçuk Üniversitesi Ziraat Fakültesi Tarım Ekonomisi Bölümü, Konya, Turkey \\ 2 Selçuk Üniversitesi Ziraat Fakültesi Tarım Ekonomisi Bölümü, Konya, Turkey \\ ${ }^{3}$ Selçuk Üniversitesi Ziraat Fakültesi Tarım Ekonomisi Bölümü, Konya, Turkey \\ ${ }^{4}$ Selçuk Üniversitesi Çumra Uygulamalı Bilimler Yüksekokulu Organik Tarım İşletmeciliği Bölümü, Konya, Turkey

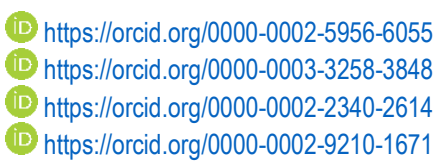

Arısoy H., Bayramoğlu Z., Ağızan K. \& Ağızan S. (2021). Global growth trend in fisheries and current situation in Turkey. Ege Journal of Fisheries and Aquatic Sciences, 38(4), 499-505. DOI: 10.12714/egejfas.38.4.11

Abstract: In recent years the most salient change in the global food sector has been witnessed in the range of fisheries. Due to the gravity of fishery, particularly in meeting the needs of an adequate and balanced diet, its total share in production, consumption and trading has been on the rise on a global scale. The aim of this study is to detect the factors impinging upon growth trend and foreign trade of global fishery sector. To that end, data from 19902017 period of 10 countries meeting $72 \%$ of global fisheries and data from Turkey have been employed. In this study panel data analysis method has been applied by using 11 cross-section data and 28 -time series. Importation and exportation models have thus been set. An increase by $100 \%$ in production of fisheries climbs exportation share by $15 \%$ and degrades importation share by $1 \%$. 1-unit increase in income heightens importation by 8 units. Slowness in the growth rate of production of fisheries can be associated with supplying the vast majority of total production by only a few select countries thus threatening global exportation of fisheries. Turkey and relevant countries could gain exportation advantage by conducting a better analysis of their existing potential.

Keywords: Fisheries, foreign trade, exportation, panel data analysis, Turkey

Öz: Son yıllarda dünya gıda sektörü içerisindeki en önemli gelişme su ürünleri alanında görülmektedir. Özellikle yeterli ve dengeli beslenme bakımından olan önemi nedeniyle dünya toplam üretimi, tüketimi ve ticareti artmaktadır. Bu çalışma ile dünya su ürünleri sektörünün gelişme trendi ve dış ticaretini etkileyen faktörlerin belirlenmesi amaçlanmıştır. Bu amaçla dünya su ürünleri üretiminin \%72'sini kapsayan 10 ülke ve Türkiye'nin 1990-2017 dönemi verileri kullanıımıștr. Çalışmada 11 yatay kesit verisi ve 28 zaman serisi kullanılarak panel veri analiz yöntemi kullanıımışır. İthalat ve ihracat modelleri kurulmuştur. Su ürünleri üretimindeki \%100'lük artı̧ ihracatı \%15 artırmakta, ithalatı \%1 azaltmaktadır. Gelirde görülen 1 birimlik artış ithalatı 8 birim artırmaktadır. Su ürünleri üretiminin artış hızının yavaşlaması, toplam üretimin büyük kısmını birkaç ülkenin karşılıyor olması dünya su ürünleri ihracatı açısından tehdit olarak değerlendirilebilir. Türkiye gibi ülkeler mevcut potansiyelini daha iyi değerlendirerek ihracat avantajı yakalayabilir.

Anahtar kelimeler: Su ürünleri, dış ticaret, ihracat, panel veri analizi, Türkiye

\section{INTRODUCTION}

In recent times policies on food security and safety have grabbed much wider attention due to a number of reasons such as; global rise in population, scarcity of agricultural lands due to misuse, rising demands in consumption, failure to stop food waste and unequal distribution of food, hunger and environmental risks. Studies suggest that world population being 7.6 billion presently will be over 9 billion in 2050 (FAO, $2017)$ and protein demand of humans will multiply by $70 \%$ (Özdemir, 2019).

An adequate and balanced diet plays a critical role in the development of societies. Currently animal protein consumption per person is a salient criterion in measuring development level of states. According to data released by World Health Organization (WHO), a healthy individual must consume $1 \mathrm{gr}$. of protein for every kilogram of total body weight and $42 \%$ of this intake should be animal-based (Özuğur et al., 2019). One of the best resources to meet protein deficiency in a cheap and effective way is fisheries of which value has now grabbed an increasing focus. Having acknowledged this trend, countries seek ways to maximally use water products to further enrich their animal protein sources. Hence, many countries have an economic and sustainable fisheries management (Düzgüneş and Erdoğan, 2008).

Fishery sector holds an economic value too by virtue of its direct or indirect links with the food and manufacturing industry, health, environment, tourism and transportation sectors. Since it has no equivalent match in food pyramid and provides a positive contribution on employment and foreign trade, significance of water-products sector climbs even higher (Anonymous, 2012).

Production of fisheries has gained rapid impetus as of post Second World War and been soaring since then. Food and Agriculture Organization (FAO) highlights water products as the fastest-growing food sector globe wide (Tatlıdil et al., 2009). Production of fisheries is practiced under two 
categories namely; sea and territorial sea hunting \& aquaculture (fish farming) in territorial seas, seas and territorial waters. A great ratio of production is through hunting but in recent years' fishery through hunting has been losing its share in total production whereas fishery through aquaculture has been following a rapid growth. One of the most apparent causes is failure to increase the quantity of products obtainable from the seas through hunting. To ensure sustainable fishery we have now reached the utmost level in the quantity of huntable fish (Anonymous, 2012).

There has been a rise in the global production of fisheries and trading. Turkey is a peninsula surrounded by seas on three sides. Turkey lies within an $8,333 \mathrm{~km}$. of seashore and $177,714 \mathrm{~km}$-long rivers. Besides it holds dam lakes of 342,377 hectare expanding each new year. Total surface area of seas and inland water resources of Turkey is measured as 25 million hectares; this figure is close to the totality of agricultural lands of Turkey (Anonymous, 2012). Irrespective of this potential Turkey's global share in the production of fisheries is $0.3 \%$, its global share in the exportation of fisheries is $0.5 \%$. Foreign-trade surplus of fisheries merely 405 million dollars (FAO, 2019).

The fishery sector that, by virtue of added-value and employment it creates, holds a strategic interest has been developing in Turkey as also witnessed globe wide. Studies that analyze the contribution of sector on national economy and foreign trade are of vital importance (Akyol and Ceyhan, 2010; Candemir and Dağtekin, 2020; Demir, 2011; Emiroğlu, 2018; Hoşsucu et al., 2001; Koşar, 2009; Sarı̈zkan, 2016; Tekelioğlu et al., 2007; Yıldırım and Okumuş, 2004). In addition, many studies have been carried out on production (Alçiçek, 2009; Başçınar, 2007; Çeliker, 2006; Demir, 2011; Doğan, 1997; Emiroğlu, 2018; Köse et al., 2010; Yüngül et al., 2012), trade (Başçınar, 2007; Dağtekin and Orhan, 2007; Kuşat and Kuşat, 2019), consumption (Akbay et al., 2013; Aydın and Karadurmuş, 2013; Bayraktar et al., 2019; Çolakoğlu et al., 2006; Dağtekin and Orhan, 2007; Dereli et al., 2016; Özuğur et al., 2019; Sağlam and Samsun, 2018; Sayğı et al., 2015; Şenol and Saygı, 2001), competition (Kuşat and Kuşat, 2019), and organization (Ünal and Yercan, 2006; Y.lmaz et al., 2009), and it is important to determine the foreign trade potential and the factors affecting this potential in order to increase competitiveness in today's conditions where the market structure is changing very rapidly. Thus, it was aimed to increase the competitiveness of Turkey in this field by determining measures, strategies and policies to improve foreign trade in fisheries products.

\section{MATERIALS AND METHODS}

Research material consists of secondary-data collected from 10 countries (China, Indonesia, India, Vietnam, USA, Russia, Japan, Peru, Bangladesh, the Philippines) that meet $72 \%$ of global-production of fisheries as well as data from Turkey.
In scientific research data categories are generically recognized and utilized as cross-section and time series, but in case there is inadequacy of monitoring the quantity in constructing applicable models, panel data model is opted for. In relation to relevant variable in data sets constructed via panel data, there is data in both time and also cross dimension. Within the context of this study too, panel data set was used in analyzing the factors affecting importation and exportation of fisheries among select countries. Panel data analysis is defined as estimation of economic relations by utilizing cross series of time dimension (Pazarlıoğlu, 2001). It is feasible to repeat the observations in panel data sets. From this point of view, it is detected that on the basis of panel data analyses repetitive variance analysis and variance analysis models are formed (Greene, 2003). In the panel-data set used in this study there are 11 cross-section data and 28-time series. This study focuses on explaining importation and exportation practices of 10 countries with the highest rate of global fish production and data from Turkey. Importation, exportation, production, consumption, income and currency parities of the said countries for the period between 19902017 were compiled and a panel data set constructed with a total of 308 observation values was formed.

The model based on panel data analysis is as follows (Greene, 2003).

$$
Y_{i t}=\alpha_{i}+\beta^{\prime} X_{i t}+u_{i t}
$$

Xit contains a $\mathrm{K}$ regressor. But the constant term is not included, $\alpha_{i t}$, is constant over time t, describing the special effect for cross-section units $i$. This is an ordinary regression model. If $\alpha_{i t}$ all units of 's are the same, this dataset can be analyzed by the ordinary least squares method and the parameters are consistent and unbiased. Panel data models are examined in two groups as fixed effects and random effects methods. The difference between these two methods is to determine a constant coefficient for each group. In the fixed effects method, each group is considered heterogeneous and the fixed coefficient for each group is estimated. However, the same constant coefficient is estimated for each group in the random effects method. Some tests are needed to decide which method to use in panel data models. These tests are the $\mathrm{F}$ test, the Breusch-Pagan test and the Hausmann test.

F test: It aims to test if panel data has fixed effect or not. Based on this test, pooled or fixed-effect panel data model is estimated. As the model is estimated via Classical Least Squares Method (LSM), F test is applied and hypothesis is tested. Given that F Statistics is significant $(<0.05) \mathrm{H}_{0}$ hypothesis is rejected. Hypotheses of $F$ test are as listed below.

$\mathrm{H}_{0}=$ Pooled Regression Model is Fit.

$\mathrm{H}_{1}=$ Fixed Effects Model is Fit. 
In the second stage, by harnessing Breusch-Pagan Test Pooled Model-Random effects, the model is tested. In a different saying it tests whether or not panel data have random effects. Model is estimated through classical LSM and by administering "Breusch-Pagan LM" test, hypothesis is tested. Given that Breusch-Pagan LM Statistics is significant $(<0.05) \mathrm{H}_{0}$ hypothesis is rejected. Hypotheses are such;

$$
\begin{aligned}
& \mathrm{H}_{0}=\text { Pooled Regression Model is Fit. } \\
& \mathrm{H}_{1}=\text { Random Effects Regression Model is Fit. }
\end{aligned}
$$

In the third stage by using Hausmann test, a choice is drawn between fixed effects model and random effects model. Based on this test fixed or random effect panel data model is estimated. To conduct Hausman test, firstly, the model should be estimated through "Random Effect Panel Data Model" method. Hypotheses of Hausmann test are as depicted below.

$$
\begin{aligned}
& \mathrm{H}_{0}=\text { Random effects Model is Fit. } \\
& \mathrm{H}_{1}=\text { Fixed effects Model is Fit. }
\end{aligned}
$$

As a result of the tests, it was determined whether the model has a random or constant effect and the estimation of the model was made with the help of the STATA package program.

In this study two models were built to explain importation and exportation. Variables mentioned in the model are given below. All of the variables out-of-parity were measured per person and included in the model.

Importation (IM): explains per person fisheries importation quantity of countries (kg/year)

Exportation (EX): explains per person fisheries exportation quantity of countries (kg/year)

Production (PR): explains per person production quantity of fisheries in countries (kg/year)

Consumption (CM): explains per person consumption quantity of fisheries in countries (kg/year)

Income (IN): explains gross-domestic-product income per person in countries (dollar/year)

Parity (PR): explains dollar parity of national currency in countries (dollar)

\section{RESULTS}

\section{Current status in fishery sector}

Data of top-ranking 10 countries in the global production of fisheries and data from Turkey are as listed in Table 1. There is a steady growth in production. Currently total production is twice above the production quantity (103 million tons to 206 million tons) computed in 1990 (FAO, 2019). Main cause of the global rise in the production of fisheries is adding new resources to present resources rather than effective management of existing resources. Indeed, there is an abundance of evidence on the diminished fish efficiency in current resources. Environmental damages, pollution of coast waters, insensible hunting are some of the negative factors on global fish population (Longer, 2000). Presently half ratio of global production of fisheries nearly 206 million tons, is met by China and Indonesia. In these countries growth in the production of fisheries outpaces the rise in entire world. Compared to year 1990, in China, production multiplied around 5 times and in Indonesia production increased approximately 7 times above.

Likewise, there is a global increase in the consumption of fisheries. While in 1990 annual consumption quantity per person was computed by $13.2 \mathrm{~kg} / \mathrm{year}$ the same percentage climbed to $19.2 \mathrm{~kg} / \mathrm{year}$ in 2017 . Countries with maximum consumption per person are listed as maritime countries such as Japan, China, Vietnam and Indonesia in which the production ratio is also at its peak. Turkey is far below the world average in terms of both production of fisheries and also in consumption per person.

There is also a corresponding climb in the global trading of fisheries. In 1990 sum of exportation value in fisheries measured as 35 billion dollars reached to 158 billion dollars in 2017. Among the most significant exporter countries are China, Norway and Vietnam respectively and these three countries constitute around one fourth of total exportation ratio. The most significant importer countries are USA, Japan and China respectively and these three countries constitute around one third of total importation ratio (FAO, 2019). All

\begin{tabular}{|c|c|c|c|c|c|c|c|}
\hline Countries & $\begin{array}{l}\text { Production } \\
\text { (tons) }\end{array}$ & $\begin{array}{l}\text { Per Person } \\
\text { Consumption } \\
\text { (kg/year) }\end{array}$ & $\begin{array}{l}\text { Exportation } \\
(000 \$)\end{array}$ & $\begin{array}{l}\text { Importation } \\
(000 \$)\end{array}$ & $\begin{array}{c}\text { Per Person } \\
\text { Production } \\
\text { (kg/year) }\end{array}$ & $\begin{array}{c}\text { Per Person } \\
\text { EX } \\
\text { (kg/year) }\end{array}$ & $\begin{array}{c}\text { Per Person } \\
\text { IM } \\
\text { (kg/year) }\end{array}$ \\
\hline China & $79,935,168$ & 39.13 & $20,701,805$ & $11,027,653$ & 55.03 & 2.94 & 3.36 \\
\hline Indonesia & $22,632,380$ & 30.95 & $4,383,228$ & 398,007 & 85.52 & 4.01 & 1.12 \\
\hline India & $11,632,313$ & 6.74 & $7,183,336$ & 113,732 & 8.69 & 1.05 & 0.03 \\
\hline Vietnam & $7,108,815$ & 36.24 & $8,586,492$ & $1,765,991$ & 75.15 & 19.28 & 6.62 \\
\hline USA & $5,480,131$ & 22.23 & $6,246,034$ & $21,842,536$ & 16.86 & 5.25 & 8.64 \\
\hline Russia & $5,065,176$ & 20.72 & $4,524,995$ & $2,025,068$ & 34.81 & 15.27 & 4.28 \\
\hline Japan & $4,295,728$ & 46.21 & $2,112,314$ & $15,352,351$ & 33.69 & 4.66 & 19.35 \\
\hline Peru & $4,285,648$ & 24.21 & $2,875,635$ & 311,286 & 136.29 & 49.98 & 4.31 \\
\hline Bangladesh & $4,134,436$ & 24.65 & 496,166 & 104,930 & 25.89 & 0.38 & 0.85 \\
\hline Philippines & $4,127,777$ & 28.68 & 883,537 & 585,047 & 39.25 & 3.06 & 4.69 \\
\hline Turkey & 627,797 & 5.03 & 862,127 & 456,745 & 7.74 & 2.01 & 3.27 \\
\hline WORLD & $205,580,364$ & 19.20 & $158,102,263$ & $148,605,591$ & 27.24 & 10.44 & 5.12 \\
\hline
\end{tabular}
over the world, the most popular fisheries globally exchanged are prawns, tuna and salmon fish (Anonymous, 2012).

Table 1. Production, consumption and foreign trade status in select countries (2017) Source: FAO (2019) 
The global ratio of total food exchange in fishery trading is also on the rise. In recent years' liberalization policies, technological innovations, improvements in processing, packaging, and transportation, as well as changes in distribution and marketing, have further accelerated this trend while facilitating the emergence of complex supply chains in which goods often cross national borders several times before final consumption (Bellmann et al., 2016).

Developing countries play a key role in global trading of fisheries. With respect to exchange value of fisheries in total, the share of developing countries group in 1990 was computed as $40 \%$ while in 2017 the ratio jumped to $52 \%$ (FAO, 2019).

\section{Analysis results}

Panel fitness of data tests were conducted for the data utilized in this research. The first test is $F$ test aimed at checking whether or not panel data renders a fixed-effect. Accordingly, as can be seen in Table 2 since $F$ Statistics is < $0.005 \mathrm{H}_{0}$ hypothesis is rejected thus for both models it is essential to apply fixed-effects regression model (Yerdelen Tatoğlu, 2013).

Another test aims to check whether or not panel data leads to a random effect. Based on this model pooled or "Random Effect Panel Data Model" is estimated. As displayed in Table 2 in both models probability values (prob.) of Breusch-Pagan LM were measured as 0.000 . This value is < $\% 5$ hence based on this equation $\mathrm{H}_{0}$ hypothesis is rejected. This finding validates that in the model fixed-term is randomly determined in the average of population and differences cause an effect equal to error term for every unit.

Based on this finding it can reasonably be argued that there is a greater advantage in using "Random Effect Panel Data Model". It was also concluded that based on $F$ test and Breusch-Pagan LM, test estimation should be processed through panel data models. That being the case, however, it is essential to make a choice between Fixed-effect and Random Effect models as both being panel data models. To that end Hausman Test was conducted to check if panel data has fixed or random effect. Based on Hausman test statistics, since both models are $>0.05$, data are fit for fixed effects model.

Table 2. F Statistics, Breusch-Pagan LM Test and Hausmann Statistics

\begin{tabular}{llll}
\hline Model & Statistics & $\begin{array}{l}\text { Value } \\
\text { Statistics }\end{array}$ & Prob. \\
\hline Exportation & F Statistics & 2670.719 & 0.000 \\
Importation & F Statistics & 16101.99 & 0.000 \\
Exportation & Breusch- & 639.1554 & 0.000 \\
& Pagan LM & 442.1815 & 0.000 \\
Importation & Breusch- & & \\
& Pagan LM & 79.09318 & 0.074 \\
Exportation & Hausmann & 3.993122 & 0.406 \\
\hline Importation & Hausmann & & \\
\hline
\end{tabular}

Source: Author's calculations
Table 3 exhibits parameters of exportation and importation model. Firstly, $R^{2}$ that validates significance of the model was analyzed. In exportation model $R^{2}$ was computed as $95 \%$, in importation model as $97 \%$. $R^{2}$ indicates explanatory power of the model and presents to what extend independent variables can affect dependent variable (Kalaycl, 2010). Significance of the model is visualized by $F$ test. Accordingly, in two models alike F Statistics was measured to have a statistical-significance level by $1 \%$. Autocorrelation problem in the model was analyzed via Durbin Watson Statistics. As a result of the DW statistics, autocorrelation could not be determined since the 1.275590 statistics included in the export model are between the minimummaximum value in the DW $5 \%$ significance level table (1.0281.850). However, since the DW test result obtained in the import model is lower than the minimum value in the test table, the autocorrelation problem has been detected. Therefore, in order to solve the autocorrelation problem, the one degree lagged values of the import model were included in the model and re-estimated.

Regarding the 11 countries selected within the scope of this research importation and exportation models have been explained via fixed-effect panel model. There is always a linear relationship between importation and exportation and this deduction has been validated in a wide array of studies too (Tatıdil et al., 2009).

Similarly, in the context of this research too, exportation and importation variable signs of both models were detected as positive as expected. It can be argued that in exportation model; $100 \%$ climb in importation quantity would lead to rise by $78 \%$ in exportation quantity. However, in importation model it is suggested that $100 \%$ climb in exportation quantity would lead to a rise of merely $6 \%$ in importation quantity (Table 3 ). Based on the results of these models the fact that importation has a greater effect on the rise of exportation could be explained by two reasons. The first reason is re-exportation. In another saying countries can re-export the kind of products imported in a lower cost margin of their own production cost. Second reason is that countries can process the products they import and then export the same products. Thus in both scenarios exportation is made dependent on importation and in such cases importation acts like the source of constant exportation.

Another parameter in these models is consumption. In exportation model consumption is statistically significant and as expected, its sign was detected to be negative. In that case it can be argued that when consumption quantity climbs by $100 \%$ exportation quantity will fall by $24 \%$. In the importation model, however, there is a significant and linear relationship between importation and consumption. In that sense, as consumption quantity rises by $100 \%$ importation quantity falls by $23 \%$. 
Table 3.Parameters of exportation and importation model

\begin{tabular}{|c|c|c|c|c|c|c|c|}
\hline \multicolumn{3}{|c|}{ EXPORTATION } & \multicolumn{5}{|c|}{ IMPORTATION } \\
\hline Variables & Coefficient & t-Statistics & Prob. & Variables & Coefficient & t-Statistics & Prob. \\
\hline Consumption & -0.241049 & -3.379675 & 0.0008 & DConsumption & 0.233546 & 1.269585 & 0.0012 \\
\hline Production & 0.158651 & 1.813343 & 0.0000 & DProduction & -0.043256 & -7.854236 & 0.0000 \\
\hline Income & $6.14 \mathrm{E}-05$ & 0.994756 & 0.3207 & DIncome & $6.23 \mathrm{E}-05$ & 3.126358 & 0.0000 \\
\hline Importation & 0.788944 & 3.631783 & 0.0003 & DExportation & 0.063561 & 2.452369 & 0.0004 \\
\hline Parity & 0.000323 & 1.920341 & 0.0558 & DParity & $-5.83 E-05$ & -3.221529 & 0.2215 \\
\hline C & 2.145 .094 & 1.661833 & 0.0976 & C & -0.456923 & -2.752169 & 0.0463 \\
\hline China & 8.927895 & & & China & 2.707073 & & \\
\hline Indonesia & 1.496104 & & & Indonesia & -0.344443 & & \\
\hline India & 2.835507 & & & India & -4.372223 & & \\
\hline Vietnam & 1.321334 & & & Vietnam & -1.347603 & & \\
\hline USA & -4.935283 & & & USA & 8.643756 & & \\
\hline Russia & 1.630721 & & & Russia & 4.322457 & & \\
\hline Japan & -2.684346 & & & Japan & -2.042774 & & \\
\hline Peru & 2.675309 & & & Peru & 0.344436 & & \\
\hline Bangladesh & -3.231482 & & & Bangladesh & 0.034670 & & \\
\hline Philippines & -0.908791 & & & Philippines & -2.345374 & & \\
\hline Turkey & 1.700477 & & & Turkey & 1.373377 & & \\
\hline$R^{2}$ & 0.955842 & & & $R^{2}$ & 0.935693 & & \\
\hline Adjusted $R^{2}$ & 0.953573 & & & Adjusted $R^{2}$ & 0.935458 & & \\
\hline S.E.of regression & 4.273755 & & & S.E.of regression & 1.156985 & & \\
\hline F-statistics & 421.3729 & & & F-statistics & 758.6582 & & \\
\hline Prob (F-statistic) & 0.000000 & & & Prob(F-statistic) & 0.000000 & & \\
\hline D.Watson stat. & 1.275590 & & & D.Watson stat. & 1.652892 & & \\
\hline
\end{tabular}

Source: Author's calculations

In production variable, on the other hand, there is an inverse relationship as for consumption. In exportation model there is a significant and linear relationship between production and exportation and if production climbs by $100 \%$ exportation escalates by $15 \%$. In importation model, there is an inverse but significant relationship between production and importation. As production jumps up by $100 \%$ importation goes down by $4 \%$. Based on these parameter results, trading of water products is remarkably effective to raise national income level since they are categorized as products with high value of exportation potential and render a rise in added value.

As we delve into the relationship between income variable and importation and exportation not any statistically significant relationship could be measured between income and exportation whilst in importation model a significant relationship was identified between income and importation. It can thus be projected that 1-unit rise in income would climb importation 8 times above. Indeed, previous studies evidenced that production of water products leads to a high elasticity in income demands (Tatlıdil et al., 2009). That being the case a change of one unit in income would lead to a greater increase in consumption. Then rising demand unviable to meet through domestic consumption would thus be met via importation.

One of the most effective factors in foreign trade is national currency value. Given that a state's national currency gains value against the currency of other nations, exportation becomes tougher for the said country while importation becomes easier. On that account parity-variable sign is expected to be positive in importation model but negative in exportation model. Within the context of this study, a significant relationship in a range of $10 \%$ could not be determined between importation and parity. Between exportation and parity, a significant and yet not positive relationship could be detected. In exportation model sign of parity variable is expected to be negative. The main reason for obtaining a positive sign is that lately there has been a value-gain against dollar in the national currency of China and Japan as holding $41 \%$ share in fish production and $14 \%$ share in exportation.

Finally, the country results are evaluated in the Table, and the differences of the countries in imports and exports of each country are shown. Accordingly, countries with a high constant coefficient have a higher impact on imports or exports. For example, in the export model, China and the USA were determined as the countries with the highest impact, and in the import model, the USA and Russia had the highest impact. In addition, the changes in the consumption, production, income, import and parity variables in the USA, Japan, Bangladesh and Philippines in the export model affect exports negatively. In the import model, it was determined that the changes in consumption, production, income, import and parity variables in Indonesia, India, Vietnam, Japan and the Philippines affected imports negatively. As a matter of fact, the USA and Japan are among the important importing countries in fisheries products, and the change in the demand for fishery products will have a significant impact on world exports. Similarly, Indonesia, India and Vietnam countries, especially China, are known as important exporters, and the differences in the production potential of these countries or depending on market conditions affect world imports significantly. For this reason, the effects of these countries on 
both exports and imports are high. In Turkey, the per capita consumption of fishery products (5.03 $\mathrm{kg} / \mathrm{year})$ is below the world average (19.20 kg/year), and it has not yet reached the desired level of competition in aquaculture. In this context, it was aimed to establish policies to increase competitiveness and it was emphasized that the factors affecting import and export should be taken into consideration.

\section{DISCUSSION}

Fisheries is acknowledged as an indispensable sector to satisfy escalating animal-protein need of global population on the rise. Consequently, all over the world and in Turkey alike there has been a continuous upward trend in production, consumption and trading of fisheries. Nevertheless, despite its geographical advantage Turkey has failed to grab the lion's share from this expanding market. In the last decades, although a major rise in production has been achieved through aquaculture, total sum of production is significantly far below Turkey's real potential. Backwardness of Turkey in the production of water products has also been echoed in its consumption and trading.

In relation to this research, it was aimed to detect certain factors affecting foreign trade of fisheries all over the world. Doubtless to say that there are many factors impinging upon foreign trade. A few of these factors are resolutions taken by international organizations such as World Trade Organization, bilateral trade agreements between countries, foreign trade policies effectuated in countries and political developments. In line with the objective of this research, by using 28 years of data obtained from 10 countries constituting $72 \%$ of total production of fisheries in the world and data from Turkey, importation and exportation models have been structured. Production, consumption, income, importation, exportation and parity independent variables were integrated into the models. Explanatory power of independent variables for these models were computed to be significantly high, thus results to obtain from the model are qualified to steer foreign-trade policies of fisheries.

In exportation model a positive relationship was unveiled between exportation and production. Thus any lag in the

\section{REFERENCES}

Akbay, C., Merak, Y., Yılmaz, H. \& Gözek, S. (2013). Türkiye'de ailelerin su ürünleri tüketiminin ekonomik analizi. KSÜ Doğa Bilimleri Dergisi, 16(3), $1-7$.

Akyol, O. \& Ceyhan, T. (2010). Gökçeada (Ege denizi) kıyı balıkçılığı ve balıkçılık kaynakları. Su Ürünleri Dergisi, 27(1), 1-5.

Alçiçek, Z. (2009). Su ürünleri sektöründe sürdürülebilirlik. Biyoloji Bilimleri Araştırma Dergisi, 2(2), 35-40.

Anonymous. (2012). The state of world Fisheries and aquaculture. Alıntılama Adresi: http://www.fao.org/3/i2727e/i2727e.pdf (10.10.2020).

Aydın, M. \& Karadurmuş, U. (2013). Trabzon ve Giresun bölgelerindeki su ürünleri tüketim alışkanlıkları. Karadeniz Fen Bilimleri Dergisi, 3(9), 5771. growth rate of global production of fisheries and supply of majority of total production by a few select countries can be evaluated as a threat for the global exportation of fisheries. Turkey and similar countries could thus grab an advantage in exportation provided that its current potential is better evaluated.

As a result, to provide competitive advantage in the aquaculture sector in Turkey, first, it is necessary to determine the production and marketing potentials of fishery products. In this context, first of all, food supply chain, supply chain and value chain analyze in aquatic products should be made and the production and marketing channels of the sector, value added elements and all factors that increase competition should be determined. For this reason, the measures to be taken to improve the competition in national and international markets in seafood are given below. These measures are;

\section{To prepare the production planning of seafood products}

2. Giving the supports by rearranging them according to the feed utilization rate and input/cost parity through cooperatives.

\section{To provide competitive power-enhancing supports}

4. To ensure their control and traceability in hunting and aquaculture practices

\section{Accelerate breeding of species that require less or no feed}

6. Considering the principles of environmental sustainability in the creation of hunting policies

7. To increase the publication and promotion activities for the consumption of fishery products

8. Reducing waste and losses by increasing cold chain applications in seafood

9. Reducing bureaucratic procedures for aquaculture facilities

\section{Establishing a fisheries market}

11. It can be listed as increasing exports by processing all kinds of aquatic products in a way that creates added value.

Başçınar, N. S. (2007). Ülkemizdeki kabuklu ve yumuşakça su ürünleri üretimi ve ihracatı. Aquaculture Studies, 2007(2), 14-17.

Bayraktar, S., Ergün, S. \& Ayvaz, Z. (2019). Ankara ve Çanakkale'de su ürünleri tüketim tercihleri ve alışkanlıklarının karşılaştıııması. Acta Aquatica Turcica, 15(2), 213-226.

Bellmann, C., Tipping, A. \& Sumaila, U. R. (2016). Global trade in fish and fishery products: an overview. Marine Policy, 69, 181-188. DOI:10.1016/j.marpol.2015.12.019

Candemir, S. \& Dağtekin, M. (2020). Türkiye su ürünleri üretimi ve yeterlilik endekslerinin tahmini. Acta Aquatica Turcica, 16(3), 409-415. DOI:10.22392/actaquatr.700858

Çeliker, S. A. (2006). Karadeniz bölgesi'nde su ürünleri avcılığı yapan işletmelerin sosyo-ekonomik analizi. Aquaculture Studies, 2006(3), 15. 
Çolakoğlu, F. A., İşmen, A., Özen, Ö., Çakır, F., Yığın, Ç. \& Ormancı, H. B. (2006). Çanakkale İlindeki Su Ürünleri Tüketim Davranışlarının Değerlendirilmesi. Su Ürünleri Dergisi, 23(3), 387-392.

Dağtekin, M. \& Orhan, A. (2007). Doğu karadeniz bölgesinde su ürünleri tüketimi, ihracat ve ithalat potansiyeli. Aquaculture Studies, 2007(3), 1414.

Demir, O. (2011). Türkiye su ürünleri yetiştiriciliği ve yem sektörüne genel bakış-Il. Süleyman Demirel Üniversitesi Eğirdir Su Ürünleri Fakültesi Dergisi, 7(1), 39-49.

Dereli, H., Çelik, R., Sayğı, H. \& Tekinay, A. (2016). Manisa ili su ürünleri tüketim ve tercihleri üzerine bir araştırma. Aquaculture Studies, 16(2), 115-128.

Doğan, K. (1997). Su ürünleri sektörü Türk ekonomisinin neresinde. Su Ürünleri Mühendisleri Derneği Dergisi, 1, 15-17.

Düzgüneş, E. \& Erdoğan, N. (2008). Fisheries management in the Black Sea countries. Turkish Journal of Fisheries and Aquatic Sciences, 8(1), 181 192.

Emiroğlu, M. (2018). Türkiye'nin Su Ürünleri Üretimi. Ankara Üniversitesi Dil ve Tarih-Coğrafya Fakültesi Dergisi, 31(1-2), 77-146.

FAO. (2017). FAO statistical yearbook 2017. Alıntllama Adresi: www.fao.org/docrep/015/i2490e/i2490e00.html (12.11.2017).

FAO. (2019). Fishing Statistics. Alıntlama Adresi: http://www.fao.org/fishery/statistics/en (21.02.2020).

Greene, W. H. (2003). Econometric analysis: Pearson Education India.

Hoşsucu, H., Tokaç, A., Kınacıgil, T., Tosunoğlu, Z., Akyol, O., Özekinci, U. \& Ünal, V. (2001). Balıkçlık sektörünün İzmir ili içindeki işleyişi ve güncel sorunları. Ege Üniversitesi Su Ürünleri Dergisi, 18(3-4), 437-444.

Kalaycı, Ş. (2010). SPSS uygulamalı çok değişkenli istatistik teknikleri (Vol. 5). Ankara: Asil Yayın Dağııım.

Koşar, İ. (2009). Türkiye'de balıkçlık istatistiklerinin iyileştrilmesi ve Avrupa Birliği uyum süreci. Su Ürünleri Dergisi, 26(2), 153-158.

Köse, S., Tokay, N., Baygar, S., Özer, T., Çolakoğlu, N. \& Alçiçek, Z. (2010). Türkiye'deki su ürünleri ișleme sektörünün durumu sorunları ve çözüm önerileri. Türkiye Ziraat Mühendisliği VII. Teknik Kongresi, 11, 15.

Kuşat, M. \& Kuşat, N. (2019). Su ürünleri sektörü rekabet gücü analizi: türkiye ve 5 lider ülke örneği. Süleyman Demirel Üniversitesi Eğirdir Su Ürünleri Fakültesi Dergisi, 15(1), 43-54.

Longer, C. (2000). Booming fish farrning industiy depleting World Fish supplies.
http://www.compassonline.org/pdf_files/PR_2000_6_28.pdf (14.07.2020).

Özdemir, N. (2019). Gıda ve tarım sektöründe küresel fırsatları takip etmek. Alıntılama Adresi: https://necmiozdemir.net/basin_kosesi/gida-ve-tarimsektorunde-kuresel-firsatlari-takip-etmek.html (08.02.2019).

Özuğur, A. K., Sarı, H. A., Gökdal, Ö. \& Atay, O. (2019). Öğrencilerin balık eti tüketim düzeyleri ve tüketim alışkanlıklarının belirlenmesinde Çine MYO örneği. Mesleki Bilimler Dergisi (MBD), 8(2), 57-63.

Pazarlıoğlu, M. V. (2001). 1980-1990 döneminde Türkiye'de iç göç üzerine ekonometrik model çalışması. Paper presented at the Çukurova Üniversitesi 5. Ulusal Ekonometri ve İstatistik Sempozyumu, Adana.

Sağlam, N. E. \& Samsun, S. (2018). Yozgat ili su ürünleri tüketim alışkanlıklarının belirlenmesi. Süleyman Demirel Üniversitesi Eğirdir Su Ürünleri Fakültesi Dergisi, 14(1), 9-16.

Sarıözkan, S. (2016). Türkiye'de balıkçlık sektörü ve ekonomisi. Aquatic Sciences and Engineering, 31(1), 15-22.

Sayğı, H., Bayhan, B. \& Hekimoğlu, M. A. (2015). Türkiye'nin İmir ve Ankara illerinde Su Ürünleri Tüketimi. Türk Tarım-Gıda Bilim ve Teknoloji Dergisi, 3(5), 248-254.

Şenol, Ş. \& Saygı, H. (2001). Su Ürünleri Tüketimi İçin Bir Ekonometrik Model. Su Ürünleri Dergisi, 18(3), 383-390.

Tatıdili, F. F., Aktürk, D., Bayramoğlu, Z. \& Fidan, H. (2009). Development trends of aquaculture in the world. Journal of Animal and Veterinary Advances, 8(11), 2291-2298.

Tekelioğlu, N., Kumlu, M., Yanar, M. \& Erçen, Z. (2007). Türkiye'de su ürünleri üretimi sektörünün durumu ve sorunları. Türk Sucul Yaşam Dergisi, 5(8), 682-693.

Ünal, V. \& Yercan, M. (2006). Türkiye'de Su Ürünleri Kooperatifleri ve Balıkçılar İçin Önemi. Su Ürünleri Dergisi, 23(1), 221-227.

Yerdelen Tatoğlu, F. (2013). Panel veri ekonometrisi: Stata uygulamalı. Beta Yayınları, İstanbul.

Yıldırım, Ö. \& Okumuş, İ. (2004). Muğla ilinde su ürünleri yetiştiriciliği ve Türkiye su ürünleri yetiştiriciliğindeki yeri. Su Ürünleri Dergisi, 21(3), 361-364.

Yılmaz, S., Erdilal, R., \& Kebapçıŏlu, T. (2009). Su ürünleri sektöründeki ekonomik organizasyonlardan üretici birlikleri. Akdeniz Üniversitesi Ziraat Fakültesi Dergisi, 22(2), 223-232.

Yüngül, M., Harlıoğlu, A. G. \& Bağcl, E. (2012). Elazığ'da su ürünleri sektörünün günümüzdeki durumu. Türk Bilimsel Derlemeler Dergisi, 5(1), 91-94. 